\title{
1 Sedimentary response of Arctic coastal wetlands to sea level
}

3 Raymond D. Ward ${ }^{1,2}$

41 Centre for Aquatic Environments, University of Brighton, Lewes Road, Brighton BN2 4GJ, 5 UK.

62 Department of Landscape Management, Estonian University of Life Sciences, Fr. R.

$7 \quad$ Kreutzwaldi 1, 51014 Tartu, Estonia.

\section{Abstract}

9 Arctic coastal wetlands are of international importance, providing a range of ecosystem services. They differ markedly from Atlantic saltmarshes in the limited development of the creek network, associated plant species, and the influence of the rapid influx of sediment during the spring thaw. This study presents the findings of research conducted in five Arctic coastal wetlands in northern Norway utilising ${ }^{210} \mathrm{~Pb}$ and ${ }^{137} \mathrm{Cs}$ radionuclide dating techniques to investigate the recent sedimentary responses of these wetlands to alterations in sea level rise. Historically, coastal wetland evolution has been driven by glacio-isostatic adjustment (GIA) with rates between $0.5-1 \mathrm{~mm} / \mathrm{yr}$, similar to sites in Scotland and the northern and eastern Baltic resulting in wetland progradation. Dating of the sedimentary horizons suggests broad agreement between sediment accretion rates derived from both the ${ }^{210} \mathrm{~Pb}$ methods and ${ }^{137} \mathrm{Cs}$ impulse dating methods with average rates of sediment accretion being between 0.3 and $1.9 \mathrm{~mm} / \mathrm{yr}$ (dependent on site and zonation). Sea level rise in the region is between 2.2 and $2.8 \mathrm{~mm} / \mathrm{yr}$ accounting for GIA, meaning that at present, sea level rise appears to be outpacing sediment accretion, resulting in negative elevation capital. The results of this study indicate that recent increases in sea level 
as a result of climate change are likely to have reversed the historical trend of progradation driven by isostatic uplift coupled with sediment accretion, suggesting that there may be losses of Arctic coastal wetland extent and associated ecosystem services in some areas.

\section{Keywords:}

Climate change, salt marshes, ${ }^{210} \mathrm{~Pb}$ dating, reversal of progradation

\section{Introduction}

The Arctic Ocean has the longest coastline $(45389 \mathrm{~km})$ in proportion to its size of any of the world's oceans (Symon et al. 2005), equivalent to the Atlantic coastline of the Americas, typically protected from winter storm wave action by sea ice by reducing the fetch over open water. However, the impacts of climate change have been predicted to be greatest within the Arctic region (IPCC, 2013) and Arctic coastal environments are currently experiencing significant reductions of summer and land-fast sea ice cover in response to global warming (Walsh et al. 2017). Many Arctic and sub-arctic coastlines are also experiencing glacio-isostatic adjustment (GIA), which have historically resulted in progradation (Martini et al. 2019), particularly when combined with sediment accretion as is typical in coastal wetlands (Ward et al. 2014). However, in many Arctic coastal settings, climate change is driving a rapid reactivation of coastal processes, challenging traditional views that Arctic coastal wetlands are stable polar environments (Symon et al. 2005). Rising temperatures and a longer growing season are likely to increase net primary productivity (Symon et al. 2005) and may increase rates of surface elevation change as a result of increased above-ground biomass promoting greater sediment 
deposition or below-ground biomass contributing to greater soil volume. Decreases in ice cover may increase the influence of wave activity in Arctic coastal wetlands (Martini et al. 2019). Furthermore, recent increases in rates of sea level rise may result in losses to Arctic coastal wetland extents, as has been reported for sites in other global regions (Spencer et al. 2016; Jankowski et al. 2017; Saintilan et al. 2018). At present, there are few data available to provide a detailed understanding of present day and historical sedimentation rates within Arctic coastal wetlands. Such data are therefore essential for making any assessment of the impacts of sea level rise within these ecosystems and of future trends in response to the continued warming of the Arctic region.

The aim of this study is to assess recent ( 150 years) rates of sediment accretion within five Arctic coastal wetlands in northern Norway (Figure 1) and assess their response to climate change. This was undertaken using radiometric dating techniques $\left({ }^{210} \mathrm{~Pb}\right.$ and $\left.{ }^{137} \mathrm{Cs}\right)$ to establish a geochronology for recent coastal wetland development and compare this with current rates of sea level rise and isostatic uplift. This study provides the first such assessment in Arctic coastal wetlands.

\section{Regional setting}

The Arctic coast of Scandinavia has average summer temperatures of $10.1^{\circ} \mathrm{C}$ and a short growing season ( 120 days). Average winter temperatures are $-3.5^{\circ} \mathrm{C}$, much warmer than most Arctic regions due to the North Atlantic Drift Current (Martini et al. 2019). As with most coastal wetlands, productivity is high and Arctic coastal wetlands support high numbers of breeding and migratory birds, which graze and provide nutrients through guano inputs (Ngai and Jefferies 2004). The bedrock of the 
catchments surrounding the fjords is composed of Precambrian-Silurian crystalline rocks (Levell, 1980) with Mesozoic sedimentary rocks at the coast (Roberts et al. 1997). Sediments in the coastal area are typical of periglacial/ glacial landscapes and include glacial moraines, glacio-fluvial deposits, fluvial deposits, sea-fjord deposits and thick marine deposits (NGU 2017). Fjords are typically between 150 and $280 \mathrm{~m}$ deep, although within the Porsangerfjord and Altafjord, where the largest coastal wetlands are found, depth is substantially less $(\sim 15 \mathrm{~m}$ at the head of the fjords) (NGU 2017). The coastline is undergoing post glacial isostatic adjustment, although rates vary between no uplift in the outer islands and $1 \mathrm{~mm} / \mathrm{yr}$ in the inner fjord heads (Eronen et al. 2001; Romundset et al. 2011). These rates are similar to areas in Scotland and parts of the Baltic states, where in some coastal wetlands, sea level rise is now outpacing isostatic uplift and sediment accretion combined (Teasdale et al. 2011; Ward et al. 2014). The predominant currents that influence this region are the Norwegian Current and the Coastal Current which flow toward the northeast and sea surface temperatures fluctuate between 5 and $11^{\circ} \mathrm{C}$ throughout the year (Eilertsen and Skarðhamar 2006), resulting in limited ice cover in the coastal zone and adjacent seas. The dominant plant species in the wetlands are: Puccinellia phryganodes, Puccinellia retroflexa borealis, Cochlearia officinalis, Carex subspathecea, Festuca rubra, Carex glareosa, Carex mackenziei, and Juncus gerardii (Martini et al. 2019).

Five study sites were selected along the Arctic coast of Norway between Tromsø $\left(69^{\circ} 40^{\prime} 58^{\prime \prime} \mathrm{N}, 18^{\circ} 56^{\prime} 34^{\prime \prime} \mathrm{E}\right)$ and Stabbursnes $\left(70^{\circ} 11^{\prime} 39^{\prime \prime} \mathrm{N}, 2^{\circ} 55^{\prime} 39^{\prime \prime E}\right)$. These five sites represent the most common coastal wetland types in Fennoscandian Arctic coastal wetlands including the two largest coastal wetlands in the region (Alta within Altafjord and Stabbursnes within Porsangerfjord, Figure $2 \mathrm{a}$ and $\mathrm{b}$ respectively) and 
the smaller fjordhead coastal wetlands, similar to those of Scotland, that are typical of the region (Birtvarre, Storfjord and Storslett, Figure $2 \mathrm{c}, \mathrm{d}$, and e respectively).

\section{Materials and methods}

\subsection{Field methods}

Two $7.5 \mathrm{~cm}$ diameter PVC cores were extracted from each site, one from the upper shore and one from the lower shore plant community. Upper and lower shore were distinguished by elevation and ecological zonation in the field. A series of small trenches were dug in a walkover survey to visually identify the representativeness of the sediment stratigraphy in the core locations. Cores were inserted to a depth of 40 $\mathrm{cm}$ or to refusal (typically an underlying pebble/ cobble bed), taking care to ensure minimum compaction $(<5 \%)$. Following extraction, cores were sealed to ensure minimal impacts on the stratigraphy and frozen until analysis in the laboratory.

\subsection{Core preparation}

Samples were extruded from the core barrel by allowing the outer core surface to thaw enabling the intact sediments to be removed with no sediment compaction. Compaction was assessed by measuring the length of the core before and after extraction and revealed no core compaction had taken place. The exterior of the cores was cleaned and split into subsamples at $0.5 \mathrm{~cm}$ intervals. All subsamples were then oven-dried at $40^{\circ} \mathrm{C}$ until they reached constant weight. Dried samples were gently disaggregated using a pestle and mortar and approximately $8 \mathrm{~g}$ was 
120 carefully weighed into cylindrical plastic vials for determination of ${ }^{210} \mathrm{~Pb}_{\text {total }},{ }^{137} \mathrm{Cs}$ and ${ }^{214} \mathrm{~Pb}$ down-core activities.

\subsection{Organic matter and particle size analysis}

124

The remaining subsamples were combusted in a muffle furnace at $450^{\circ} \mathrm{C}$ for 24 hours (Lima et al. 2020). This temperature was used to limit overestimations of organic matter through loss of clay-bound water and carbonates, as often occurs at higher temperatures (Sun et al. 2009), as well as achieve complete combustion of all organic material. Sediment samples with organic material removed were placed in a Malvern Mastersizer 2000 laser particle size analyser and data were classified using the Wentworth (1922) scale. $10 \mathrm{ml}$ of sodium hexametaphosphate was added and samples were placed on a shaker for 30 minutes prior to particle size analysis to deflocculate the particles. Samples also underwent sonication and the results of three separate analytical runs were averaged (standard error $<1 \%$ ). The coefficient of sorting was calculated using the Folk and Ward (1957) method to identify any differences in depositional energy over time.

\subsection{Geochronology}

Chronologies using measured activity profiles of ${ }^{210} \mathrm{~Pb}$ (half-life $\left(t^{1} / 2\right)=22.26$ years) are widely used to evaluate sediment accretion rates in coastal wetlands (Callaway et al. 1997; Teasdale et al., 2011; Ward et al., 2014; Arias-Ortiz et al. 2018). Using gamma spectrometry, both ${ }^{210} \mathrm{~Pb}$ and ${ }^{137} \mathrm{Cs}$ can be determined and ${ }^{137} \mathrm{Cs}$ can be used to validate ${ }^{210} \mathrm{~Pb}$ derived dating. Sedimentation rates were calculated using the Constant Rate of Supply (CRS) and the Constant Flux:Constant Sedimentation 
144 (CF:CS) models, as outlined in Appleby and Oldfield (1992) and Appleby (2001). The 145 CF:CS model provides average sedimentation rates over the whole dated stratigraphy of the cores determined using the fit of a least squares regression of the natural log of ${ }^{210} \mathrm{~Pb}_{\text {excess }}$ activity against depth. The CRS model uses inventories to calculate specific ages for soil horizons where the total inventory within the core is determined from the sum of ${ }^{210} \mathrm{~Pb}_{\text {excess }} \times$ Dry bulk density $\times$ thickness of the core sub sample. Detection limits depend on a range of variables including the gamma of the energy radionuclide, count time and sample mass (Teasdale et al. 2011). However, these were typically $\sim 3 \mathrm{~Bq} / \mathrm{kg}$ for ${ }^{210} \mathrm{~Pb}$, and $0.2 \mathrm{~Bq} / \mathrm{kg}$ for ${ }^{137} \mathrm{Cs}$, for a 450,000 second count time. In all cases activity error values were $<5 \%$.

154 In Norway, there is a clear signature from global atmospheric inputs of ${ }^{137} \mathrm{Cs}$ that occurred in 1963 prior to the signing of the weapons test ban treaty (Ritchie and McHenry 1990), as well as a signature from ${ }^{137}$ Cs deposition as a result of the Chernobyl disaster in $1986 .{ }^{210} \mathrm{~Pb}$ from atmospheric deposition has not varied significantly since records began (Jensen 1996, Paatero et al. 2015), and there is little addition from marine sources through scavenging in this region (Kuzyk et al. 2013) meaning that there has been a constant rate of supply, a requirement for the CRS method. Atmospheric deposition of ${ }^{137} \mathrm{Cs}$ has been noted to have high spatial heterogeneity and there is a paucity of data, thus it was not possible to use the inventory ratio between ${ }^{137} \mathrm{Cs}:{ }^{210} \mathrm{~Pb}$ to assess erosion occurrences (Plater and Appleby 2004).

Down-core activity profiles were determined using a Canberra well-type ultra-low background HPGe gamma ray spectrometer at the University of Brighton. Spectra for all radionuclides were accumulated using a 16k channel integrated multichannel analyser and analysed using the Genie ${ }^{\mathrm{TM}} 2000$ system. Energy and efficiency 
calibrations were carried out using a bentonite clay standard spiked with a mixed gamma-emitting radionuclide standard, QCYK8163, and checked against an IAEA marine sediment certified reference material (IAEA 135).

\subsection{Impacts of sea level rise}

Total area predicted to be lost by 2100 were calculated in ArcGIS 10.7.1 for each site based on rates of local sea level rise accounting for average accretion rates (derived from the ${ }^{210} \mathrm{~Pb}$ CRS method) and isostatic uplift values compared to tide gauge recorded rates of sea level increase. Area loss was accounted for using LiDAR data collected by the Norwegian Mapping Authority using the same methods illustrated in Ward et al. (2016b). Whilst rates of sediment accretion varied depending on the method used (CF:CS, CRS and ${ }^{137} \mathrm{Cs}$ ), the trends, particularly the reversal of progradation, were broadly similar for all sites and ecological zones.

\section{Results}

\subsection{Sediment characteristics}

Within all ten cores at all sites there was a shallow stratigraphy recorded (Figure 3). As can be seen, the maximum depth recorded in the coastal wetland sediments was $33 \mathrm{~cm}$ in the Storslett upper shore core and the shallowest recorded in the Birtvarre upper shore core $(9 \mathrm{~cm})$. Below this depth a layer of pebbles and cobbles, most likely glaciofluvial deposits, was recorded in the field. The upper sections of the cores are characterised by an organic rich unit with a dense root matrix of varying thickness dependant on site. In site variation in organic unit thickness was not found 
to vary greatly. The percentage of organic matter in this unit ranged between 4 and 5 $\%$ in the Alta lower and upper shore cores respectively, located adjacent to the largest river in the area, and 40 to $52 \%$ in the Birtvarre lower and upper shore cores respectively. The organic rich upper unit in the stratigraphy fades into a more minerogenic unit, predominantly grey sand in both cores from Alta, Birtvarre, and Storfjord as well as in the Stabbursnes upper shore and Storslett lower shore cores. In the Stabbursnes lower shore core, minerogenic sediments below the organic unit are oxidised to $27 \mathrm{~cm}$, then anoxic grey below to the bottom of the core. The same is noted in the Storslett upper shore core at a depth of $9 \mathrm{~cm}$.

Particle size analysis shows that the bulk of the sediment is sand at all sites, with the exception of Storfjord where the upper layers are predominantly silt (Figure 4). Mean D50 values for each core are: Alta 290 and $246 \mu \mathrm{m}$, Stabbursnes 241 and $546 \mu \mathrm{m}$, Birtvarre 75 and $238 \mu \mathrm{m}$, Storfjord 88 and $68 \mu \mathrm{m}$, and Storslett 291 and $82 \mu \mathrm{m}$ for lower shore and upper shore respectively.

Down core sorting coefficient values varied from $1.5-3.2$ at Alta, $1.7-4.3$ at Stabbursnes,1.6 and-3.7 at Birtvarre, $1.8-4.3$ at Storfjord, and 1.6 - 2.4 at Storslett classified as well sorted to normally sorted. Variations are evident between sites, and are greatest at the two larger and less sheltered sites (Alta and Stabbursnes), and Birtvarre. Down core variation is most evident in the Alta upper shore core (increasing sorting towards the surface), Stabbursnes lower and upper shore cores (episodic variation particularly high values around the 1970s), and Birtvarre upper shore (also high values around the 1970s). 


\subsection{Radionuclide dating}

${ }^{210} \mathrm{~Pb}$ values decline exponentially downcore, starting from values of $100-350 \mathrm{~Bq} / \mathrm{kg}$ at all sites with the exception of Alta where values were substantially lower (18 and $48 \mathrm{~Bq} / \mathrm{kg}$ within the lower shore and upper shore cores respectively) (Figure 5). Background ${ }^{210} \mathrm{~Pb}$ values were between 6 and $36 \mathrm{~Bq} / \mathrm{kg}$. The lower values recorded at Alta as well as the decreases in values in both Birtvarre cores and the Stabbursnes upper shore core, are likely due to erosion of surface sediment (Alta), or influxes of older sediment (Birtvarre both cores and Stabbursnes upper shore). Maximum error values were $<5 \%$ in all cases for ${ }^{210} \mathrm{~Pb},{ }^{214} \mathrm{~Pb}$ and ${ }^{137} \mathrm{Cs}$, where necessary longer count times were required to obtain this level of precision.

The results from the CF:CS linear regressions, show that all regressions were significant $(p<0.0001)$, and the strength of the relationship $\left(R^{2}\right)$ varied between 0.4 and 0.9) (Figure 6). Average sediment accretion rates varied between 0.2 and 1.7 $\mathrm{mm} / \mathrm{yr}$, with typically higher accretion rates recorded in the lower shore with the exception of Stabbursnes and Storfjord where they were broadly the same (Table 1).

Using the CRS method for dating the sediments, the oldest dateable sediments were laid down in the 1870s and the majority of the other cores between 1870 and 1920 , which is within the generally accepted limit of detection for ${ }^{210} \mathrm{~Pb}$ dating $(100-150$ years) (Figure 7a-j). Not all cores were able to be dated that far back due to limits of detection for ${ }^{210} \mathrm{~Pb}$ using gamma spectroscopy including Alta lower shore (1944) and Stabbursnes upper shore (1922) (Figure 7a, d), although there are questions as to the reliability of the gamma profile for those cores.

238 Average rates of sediment accretion calculated using ${ }^{210} \mathrm{~Pb}$ CRS method are quite low for all sites varying from $0.3 \mathrm{~mm} / \mathrm{yr}$ in the Storslett upper shore core to $1.8 \mathrm{~mm} / \mathrm{yr}$ 
240 in the Alta lower shore core (Table 1). Similar rates are found using ${ }^{137} \mathrm{Cs}$ dating where values range between 0.7 and $0.4 \mathrm{~mm} / \mathrm{yr}$ (1963 and 1986 derived dates) both recorded within the Storslett upper shore core, and $1.9 \mathrm{~mm} / \mathrm{yr}(1963)$ and $2.1 \mathrm{~mm} / \mathrm{yr}$ (1986) derived from the Alta upper shore and Storfjord lower shore cores respectively (Table 1$)$.

At Stabbursnes, Storfjord and Storslett, sediment accretion is higher in the lower shore than the upper shore over both the 1963 and 1986 to present time periods. However, using the average sediment accretion rates derived from the ${ }^{210} \mathrm{~Pb} \mathrm{CRS}$ method, Alta, Birtvarre and Storslett exhibit higher values in the lower shore than upper shore (Table 2).

At Alta, within both the lower and upper shore cores, there are very high peaks in sediment accretion rates in the early 1990s and lower peaks early 1940s (Figure 7a, b). At Stabbursnes, similar trends in sediment accretion rates are noted in the lower and upper shore cores, with peaks in the late 1990s / early 2000s, mid - late 1950s and 1920's (Figure 7c, d). Within both the Birtvarre lower and upper shore cores, there are three corresponding peaks in sediment accretion rates in the early 1990s, mid 1970s and late 1950s. There are two additional peaks in sediment accretion rates that are only noted in the Birtvarre lower shore core, which occur in 2007, 1966, and 1935, which correspond with decreases in sediment accretion in the upper shore core (Figure 7e, f). This could potentially be due to erosion of the upper shore and deposition in the lower shore. Within the Storfjord lower shore core, there was very little variation in sediment accretion rates over the recorded time period and these values were low (Figure 7g). The highest recorded value for sediment accretion rates in this core was in the 1930s and corresponds to a similar maximum recorded value in the Storfjord upper shore core (Figure 7h). At Storslett, there was 
very little variation in sediment accretion rates within the upper shore and values here were low (Figure 7i). However, within the Storslett lower shore core sediment accretion rates were higher than in the lower shore and had four peaks at 2014, early 2000s, mid 1980s and early 1900s (Figure 7j).

\section{$4.3^{137}$ Cs dating}

Within all cores there is evidence of post-depositional relocation of ${ }^{137} \mathrm{Cs}$ as this is found within surface sediments and quite deep in the core prior to the 1940s in some cases. All cores show at least two clear peaks (Figure 8a-j), the deeper peak corresponds to 1963 above ground nuclear weapons testing, and the shallower peak corresponds to the 1986 Chernobyl nuclear disaster.

The downcore profile for ${ }^{137} \mathrm{Cs}$ within the Alta cores shows the two highest peaks in activity at $4.25 \mathrm{~cm}$ and $6.75 \mathrm{~cm}$ with the lower shore core and $5.75 \mathrm{~cm}$ and $8.25 \mathrm{~cm}$ in the upper shore core. However, there are smaller peaks and variations in the lower shore core and an extended peak in the upper shore core suggesting that there has been post depositional relocation of this radionuclide at this site (Figure 8a, b) and potential deposition of older sediment. Despite this, there isn't a substantial difference between sediment accretion rates derived from this method and the ${ }^{210} \mathrm{~Pb}$ results (Table 2).

\subsection{Impacts of sea level rise}

As a result of the low sediment accretion rates it is likely that there will be a substantial loss of the wetland sites due to sea level rise. In most instances there is a 
possibility of landward migration as a result of limited constraints by hard

289

290

291

292

293

294

295

296

297

298

299

300

301

302

303

304

305

306

307

308

309

310

311 infrastructure (Figure 2), although this is likely to result in erosion of the current forest interior and this is not accounted for in this scenario. As can be seen in Table 3, net sea level rise rates are likely to be highest at Stabbursnes $(1.6 \mathrm{~mm} / \mathrm{yr})$ and Birtvarre (1.2 mm/yr), and lowest Alta $(0.4 \mathrm{~mm} / \mathrm{yr})$, followed by Storslett $(0.7 \mathrm{~mm} / \mathrm{yr})$ and Storfjord $(0.9 \mathrm{~mm} / \mathrm{yr})$. Losses in area by 2100 are likely to be in the region of $72.2 \%$ at Alta, $88.1 \%$ at Stabbursnes, 55.3\% at Birtvarre, $31.7 \%$ at Storfjord and $29.9 \%$ at Storslett (Table 4).

\section{Discussion}

\subsection{Geochronology and sediment accretion rates}

The results of this study show that there is likely to have been some postdepositional mobility of ${ }^{137} \mathrm{Cs}$ in the cores as is evident from the location of this radionuclide throughout the profile in most cores (with the exception of Storslett upper shore, Figure 7j) and the broad peaks that were evident in the Storfjord cores (Figure $7 \mathrm{~g}, \mathrm{~h}$ ). Previous studies have shown that soils with high proportions of organic matter are likely to exhibit lower retention of ${ }^{137} \mathrm{Cs}$ within the deposited profile than in soils with low soil organic matter (Rosen et al. 2009; Ward et al. 2014). In the studied Arctic coastal wetlands, values of organic matter varied from an average of $\sim 3 \%$ to $50 \%$ in the upper $10 \mathrm{~cm}$ of the cores, which make up the dateable horizons using ${ }^{210} \mathrm{~Pb}$ in these cores. Soils were predominantly sand with the exception of the upper $5 \mathrm{~cm}$ of the Storfjord cores (predominantly silt), and some sites including the upper shore cores from Stabbursnes and Birtvarre also contained significant gravel fractions (Figure 4). In a modelling study undertaken by Borretzen and Salbu (2002), 
312 results showed that a large proportion of ${ }^{137} \mathrm{Cs}$ in soils stays readily mobile whilst a smaller fraction rapidly adheres to clay particles and provides a stable marker in the soil profile. The low clay content in the soils of the studied Arctic coastal wetlands is likely to have influenced the retention of ${ }^{137} \mathrm{Cs}$ in the soil profile as has been noted in previous studies (Walling and He, 1993; Cundy and Croudace, 1996; Rosen et al. 2009). The large interstitial spaces in the soil matrix in these sites is likely to result in substantial horizontal percolation of incoming water as a result of high horizontal pore water pressure during tidal or wind driven inundation. In previous studies this has been shown to result in relocation of ${ }^{137} \mathrm{Cs}$ to depths that predate the occurrence of this artificial radionuclide (Thompson et al. 2001; Teasdale et al. 2011; Ward et al. 2014). In spite of the noted post depositional remobilisation of ${ }^{137} \mathrm{Cs}$, there were two clear peaks in activity for this radionuclide recorded within the sediment profile in all cores (Figure 8). Within Arctic Norway these are likely to be records of the atmospheric deposition of ${ }^{137} \mathrm{Cs}$ from two noted events. The peak located at shallower depths in the sediment profile represents deposition from the 1986 Chernobyl disaster, whose plume travelled northwards from Ukraine up through the Baltic States and over Fennoscandia before travelling south over the UK. The peak located deeper in the sediment profile is related to pre-1963 above ground nuclear weapons testing and resultant global deposition of ${ }^{137} \mathrm{Cs}$. Within UK sediments, the 1963 peak is typically the larger (greater activity) (Teasdale et al. 2011), whereas in the Baltic States the larger peak is typically from the Chernobyl disaster due to the greater deposition in this area as a result of the proximity to the incident along the path of the plume (Ward et al. 2014). In the Arctic coastal wetland sites from this study, there were some sites (notably Storfjord, Stabbursnes, and Birtvarre upper 
337 related horizon, and others (notably Alta lower shore, Birtvarre lower shore and

338 Storslett) where this was lower. It is likely that the initial activity of ${ }^{137} \mathrm{Cs}$ at deposition for both events were closer in magnitude than has been recorded either in the UK or

340 Estonia, hence the similarity in levels of activity for these radionuclide marker

341 horizons. Considering the broad agreement in sediment accretion rates between the $342{ }^{210} \mathrm{~Pb}$ and ${ }^{137} \mathrm{Cs}$ methods, post depositional remobilisation is unlikely to have compromised the use of ${ }^{137} \mathrm{Cs}$ for dating purposes.

344

All cores showed a near exponential decline in ${ }^{210} \mathrm{~Pb}$, suggesting that this was derived predominantly from atmospheric deposition. This is an important assumption for the CRS method for dating sediments using ${ }^{210} \mathrm{~Pb}$ (Appleby and Oldfield 1992). This radionuclide is less likely to be influenced by post depositional remobilisation than ${ }^{137} \mathrm{Cs}$. However, it is clear that there are substantially lower activities for ${ }^{210} \mathrm{~Pb}$ in the Alta cores, particularly the lower shore core (Figure 5), which also exhibits a curtailed exponential decay with depth. This suggests that there may have been erosion in the upper sections of the core. Similar results were found by Andersen et al. (2000) and Ward et al. (2014), which showed evidence of recent reworking of sediments in upper core profiles in the Humber estuary and Eastern Baltic coastal wetlands respectively.

The use of ${ }^{137} \mathrm{Cs}$ and ${ }^{210} \mathrm{~Pb}$ provide an important geochemically independent comparison for dating of sediments (Teasdale et al. 2011) and the broad agreement in sediment accretion rates from these two methods suggests that the results are valid and robust.

\subsection{Alterations in sediment accretion rates over time}


361 The historical development of Arctic coastal wetlands in Norway have followed

similar patterns to those of many sites in the Canadian and Russian Arctic, Scotland and the northern and eastern Baltic where isostatic uplift rates have resulted in progradation of coastal wetlands into formerly lower intertidal areas (Teasdale et al. 2011; Ward et al. 2014; Martini et al. 2019). Current rates of sea level rise are currently $2.8 \mathrm{~mm} / \mathrm{yr}$ at Alta, Birtvarre, Storslett, and Storfjord, and $2.2 \mathrm{~mm} / \mathrm{yr}$ at Stabbursnes considering glacio-isostatic adjustment (Simpson et al. 2015). These are much lower than global average rates of sea level rise, which are in the region of $3.2 \mathrm{~mm} / \mathrm{yr}$, suggesting that there is at least a partial offset of sea level rise as a result of glacio-isostatic adjustment. Average sediment accretion rates for Alta over the dateable history using ${ }^{210} \mathrm{~Pb}(100-150$ years) are $1.8 \mathrm{~mm} / \mathrm{yr}$ and $0.9 \mathrm{~mm} / \mathrm{yr}$ (Table 1) within the lower shore and upper shore wetland plant communities respectively. This suggests that at this site, sediment accretion, combined with isostatic uplift, is likely to result in a negative surface elevation change, with resultant losses in area, particularly within the upper shore. At none of the sites are average sediment accretion rates (Table 1) in excess of current rates of sea level rise, even accounting for reported rates of isostatic uplift (Eronen et al. 2001). This is likely to be exacerbated in the upper shore plant community at Birtvarre and Storslett and in the lower shore at Stabbursnes and Storfjord, where sediment accretion rates were lowest. The results of the LiDAR derived inundation model evaluating potential losses in area of the wetlands using average CRS derived accretion rates compared with GIA corrected rates of sea level rise for the area suggest that within the current borders of all sites there are likely to be losses 29.9 and $81.1 \%$ of the total area. However, whilst this takes into account geomorphology within the site it does not take into account other factors that may influence resilience to sea level rise 
including landward migration, increases in sediment accretion related to more frequent inundation and alterations to sediment supply as a result of changes in terrestrial runoff. At the Alta and Stabbursnes sites.there were several periods of more rapid sediment accretion, which were linked to periods of higher than average precipitation and associated spring runoff (MET Norway 2019). Both of these sites appear to derive their sediments predominantly from fluvial sources and there was a notable increase in particle size (Figure 4) related to this period of increased run off and sediment accretion rates (Figure 7). At Birtvarre and Storfjord even during periods of high sediment accretion, rates did not exceed those of sea level rise, suggesting that sediment accretion combined with isostatic uplift is not enough to keep pace with current rates of sea level rise in this area. In the Storlsett lower shore plant community recent rates of sediment accretion have been in excess sea level rise, and in the last 5 years these have been far in excess of sea level rise (5.4 $\mathrm{mm} / \mathrm{yr}$, Figure 7). This is not the case for the upper shore plant community, which mudflat and pioneer species emerging, something that was noticeable at the Alta and Stabbursnes sites but not Birtvarre and Storfjord. The reversal of progradation of shore plant communities and conversion to lower shore in temperate salt marshes as 410 noted by Baily and Pearson (2007). However, sediment accretion is not the only 
411 factor that drives responses to sea level rise in coastal wetlands, as has been noted

412 by several authors (Krauss et al 2013; Ward et al. 2016a, Schuerch et al. 2018).

413 Organic inputs have been suggested to have a substantial influence on surface 414 elevation change within tropical coastal wetlands (Krauss et al. 2013), although this 415 has not been investigated for colder environments. However, several studies have noted that climate change will result in increased temperatures and a longer growing season in high latitude areas, which is likely to lead to increased productivity (Yu et al. 2017; Martini et al. 2019) and greater organic matter in the sediment matrix (Stagg et al. 2016; Ward et al. 2016c), which is likely to contribute to increases in surface elevation. Horizontal migration of the studied Arctic coastal wetlands is also a possibility where there are no geomorphic or anthropogenic constraints as is the case at Alta, Birtvarre, Storslett and Storfjord, where there is a low elevation forest area adjacent. Many Arctic sites are characterised by low population density, limited infrastructure, and typically either a forest or freshwater marsh interior adjacent to coastal wetlands (Martini et al. 2019). Thus, it is unlikely that there will be large scale losses in extent, as has been suggested for global coastal wetlands by Schuerch et al. (2019), although they did not consider Arctic coastal wetlands in their analysis. However, there may be geomorphic constraints in some areas of Norway, as has been noted for Stabbursnes, where there is a rapid increase in elevation adjacent to the coastal wetland in this highly mountainous area.

\section{Conclusions}

433 Arctic coastal wetlands in Norway have relatively shallow organic rich sediments compared to temperate counterparts and typically consist of coarser grains, in some 
cases significant proportions of gravel, although in most sites these consist predominantly of sand. Despite evidence of post depositional mobility of ${ }^{137} \mathrm{Cs}$ in the sediment profile, there was broad agreement in sediment accretion rates calculated using these marker horizons and the ${ }^{210} \mathrm{~Pb}$ CRS method. There were clear peaks associated with the pre-1963 nuclear weapons testing and the 1986 Chernobyl nuclear disaster. This study provides the first assessment of the impacts of climate change on the sedimentary development of Arctic coastal wetlands and shows that there appears to be a reversal in the historical trend of progradation in these ecosystems. This follows similar trends reported for Scotland and South Estonia, where recent slowing of glacio-isostatic adjustment processes and / or increases in rates of sea level rise have resulted in negative surface elevation change. These alterations in geomorphic processes may be somewhat alleviated by the potential for migration inland or through increased input of organic matter partially easing the balance in surface elevation change.

\section{Acknowledgements}

451 This research has been supported by SETRIF funding from the University of

452 Brighton. Many thanks to Dr Katya Solyanko for assistance in the field and Karen 453 Bowles in the lab and the two anonymous reviewers for their comments. 
463 Table and Figure captions:

464

465 Figure 1: Location of the Arctic coastal wetland study sites in northern Norway.

466

467

468

469

470

471

472

473

474

475

476

477 
482 Figure 2: Selected coastal wetland study sites (a Alta, b Stabbursnes, c Birtvarre, d 483 Storfjord, and e Storslett) are located at fjordheads, with the exception of 484 Stabbursnes, which is located on a shallow coastal shelf between the mainland and 485 a small island on the western side of Porsangerfjord. Current area is shown bordered 486 by red and predicted losses of the wetland as a result of sea level rise are shown in 487 the blue shading.

488

489

490

491

492

493

494

495

496

497 
502 Figure 3: Results from loss on ignition analysis, showing percentage soil organic 503 matter down core for each site (a: Alta lower shore; b: Alta upper shore; c: 504 Stabbursnes lower shore; d: Stabbursnes upper shore; e: Birtvarre lower shore; f: 505 Birtvarre upper shore; g: Storfjord lower shore; h: Storfjord upper shore; i: Storslett 506 lower shore; and j: Storslett upper shore).

507

508

509

510

511

512

513

514

515

516

517

518 
523 Figure 4: Results from the laser particle size analysis D10, D50 and D90 values for

524 all cores (a: Alta lower shore; b: Alta upper shore; c: Stabbursnes lower shore; d:

525 Stabbursnes upper shore; e: Birtvarre lower shore; f: Birtvarre upper shore; g:

526 Storfjord lower shore; h: Storfjord upper shore; i: Storslett lower shore; and j:

527 Storslett upper shore).

528

529

530

531

532

533

534

535

536

537

538

539

540 
544 Figure 5: ${ }^{210} \mathrm{~Pb}_{\text {excess }}$ activity/depth profiles (circles) for all cores with ${ }^{214} \mathrm{~Pb}$ activity 545 shown (triangles) as a proxy for ${ }^{226} \mathrm{Ra}$ and ${ }^{210} \mathrm{~Pb}_{\text {supported }}$ (a: Alta lower shore; b: Alta 546 upper shore; c: Stabbursnes lower shore; d: Stabburnses upper shore; e: Birtvarre 547 lower shore; f: Birtvarre upper shore; g: Storfjord lower shore; h: Storfjord upper 548 shore; i: Storslett lower shore; and j: Storslett upper shore).

549

550

551

552

553

554

555

556

557

558

559

560 
565 Figure 6: Natural logarithm of ${ }^{210} \mathrm{~Pb}_{\text {excess }}$ plotted against depth used for the CF:CS or 566 estimations of average sedimentation over the entire age/depth period (a: Alta lower 567 shore; b: Alta upper shore; c: Stabbursnes lower shore; d: Stabburnses upper shore; 568 e: Birtvarre lower shore; f: Birtvarre upper shore; g: Storfjord lower shore; h: Storfjord 569 upper shore; i: Storslett lower shore; and j: Storslett upper shore). 
586 Figure 7: Calculated rates of sediment accretion for all sites plotted against $587{ }^{210} \mathrm{~Pb}_{\text {excess }}$ CRS modelled age (a: Alta lower shore; b: Alta upper shore; c: 588 Stabbursnes lower shore; d: Stabbursnes upper shore; e: Birtvarre lower shore; f: 589 Birtvarre upper shore; g: Storfjord lower shore; h: Storfjord upper shore; i: Storslett 590 lower shore; and j: Storslett upper shore).

591

592

593

594

595

596

597

598

599

600

601

602

603 
607 Figure 8: Downcore profile of ${ }^{137} \mathrm{Cs}$ from all cores at all sites (a: Alta lower shore; b: Alta upper shore; c: Stabbursnes lower shore; d: Stabbursnes upper shore; e: 609 Birtvarre lower shore; f: Birtvarre upper shore; g: Storfjord lower shore; h: Storfjord 610 upper shore; i: Storslett lower shore; and j: Storslett upper shore). 
626 Table 1: Average rates of sediment accretion $(\mathrm{mm} / \mathrm{yr})$ derived from the CF:CS and

627 CRS methods using ${ }^{210} \mathrm{~Pb}$ for all five sites as calculated for the low and high marsh 628 zones.

629

630

631

632

633

634

635

636

637

638

639

640

641

642

643 
645 Table 2: Average rates of sediment accretion $(\mathrm{mm} / \mathrm{yr})$ derived from ${ }^{210} \mathrm{~Pb}$ and ${ }^{137} \mathrm{Cs}$ 646 dating methods for all five sites as calculated for the low and high marsh zone data 647 since 1963 and 1986 for comparison.

648

649

650

651

652

653

654

655

656

657

658

659

660

661

662

663 
665 Table 3: Maximum average rates of sediment accretion derived from the CRS 666 method, galcio-isostatic adjustement (GIA) corrected rates of sea level rise (SLR), 667 and net sea level rise within the sites taking into account GIA, eustatic forcing and 668 sediment accretion.

669

670

671

672

673

674

675

676

677

678

679

680

681

682

683 
685 Table 4: Current area of the coastal wetlands at each site. Predicted area of the 686 wetland as a result of local sea level rise is shown together with the percentage total 687 loss. Care should be taken that this does not account for environmental feedback, 688 nor factors other than sea level rise including potential for migration inland.

689

690

691

692

693

694

695

696

697

698

699

700

701

702

703 


\section{References}

706

707

708

709

710

711

712

713

714

715

716

717

718

719

720

721

722

723

724

725

726

Andersen, T., Mikkelsen, O., Møller, A. and Pejrup, M. (2000). Deposition and mixing depths on some European intertidal mudflats based on ${ }^{210} \mathrm{~Pb}$ and ${ }^{137} \mathrm{Cs}$ activities. Continental Shelf Research 20: 1569-1591.

Appleby, P. (2001). Chronostratigraphic techniques in recent sediments. tracking environmental change using lake sediments. Kluwer Academic Publishers, Netherlands, pp. 171-203.

Appleby, P. and Oldfield, F. (1992). Application of lead-210 to sedimentation studies. In: Harmon, S. (Ed.), Uranium series disequilibrium: application to Earth, marine and environmental science. Oxford Scientific Publications, UK, pp. 731-783.

Arias-Ortiz, A., Masqué, P., Garcia-Orellana, J., Serrano, O., Mazarrasa, I., Marbà, N., Lovelock, C.E., Lavery, P.S. and Duarte, C.M. (2018). Reviews and syntheses: $\mathrm{Pb}$-derived sediment and carbon accumulation rates in vegetated coastal ecosystems - setting the record straight. Biogeosciences 15: 6791-6818.

Baily, B. and Pearson, A. (2007). Change detection mapping and analysis of salt marsh areas of central southern England from Hurst Castle Spit to Pagham Harbour. Journal of Coastal Research, 23(6): 1549-1564.

Borretzen, P. and Salbu, B. (2002). Fixation of Cs to marine sediments estimated by a stochastic modelling approach. Journal of Environmental Radioactivity, 61:1-20.

Callaway, J., DeLaune, R. and Patrick Jr., W.H. (1997). Sediment accretion rates from four coastal wetlands along the Gulf of Mexico. Journal of Coastal Research, 13(1): 181-191. 
727 Cundy, A. and Croudace, I. (1996). Sediment accretion and recent sea-level rise in 728 the Solent, Southern England: inferences from radiometric and geochemical studies. 729 Estuarine Coastal Shelf Science, 43: 449-467.

730 Eilertsen, H.C and Skarðhamar, J. (2006). Temperatures of north Norwegian fjords 731 and coastal waters: variability, significance of local processes and air-sea heat exchange. Estuarine, Coastal and Shelf Science, 67(3): 530-538.

733 Eronen, M., Glückert, G., Hatakka, L., van de Plassche, O., van der Plicht, J. and 734 Rantala, P. (2001). Rates of Holocene isostatic uplift and relative sea-level lowering 735 of the Baltic in SW Finland based on studies of isolation contacts. Boreas 30: 17-30.

736 Folk, R.L. and Ward, W.C. (1957). A study in the significance of grain-size 737 parameters. Journal of Sedimentary Petrology, 27: 3-26.

738 IPCC (2013). Climate change 2013: summary for policymakers. Cambridge 739 University Press, UK.

740 Jankowski, K., Törnqvist, T. and Fernandes, A. (2017). Vulnerability of Louisiana's 741 coastal wetlands to present-day rates of relative sea-level rise. Nature 742 Communications, 8: 14792.

743 Jensen, A. (1996). Historical deposition rates of $\mathrm{Cd}, \mathrm{Cu}, \mathrm{Pb}$, and $\mathrm{Zn}$ in Norway and 744 Sweden estimated by ${ }^{210} \mathrm{~Pb}$ dating and measurement of trace elements in cores of 745 peat bogs. Water Air Soil Pollution, 95: 205-220.

746 Krauss, K.W., McKee, K.L., Lovelock, C.E., Cahoon, D.R., Saintilan, N., Reef, R. and 747 Chen, L. (2014). How mangrove forests adjust to rising sea level. New Phytologist, 748 202: 19-34. 
749 Kuzyk, Z.A., Gobeil, C. and Macdonald, R.W. (2013). ${ }^{210} \mathrm{~Pb}$ and ${ }^{137} \mathrm{Cs}$ in margin

750

751

752

753

754

755

756

757

758

759

760

761

762

763

764

765

766

767

768

769

770

771

sediments of the Arctic Ocean: Controls on boundary scavenging. Global Biogeochemical Cycles, 27: 422-439.

Levell, B.K. (1980). A late Precambrian tidal shelf deposit, the Lower Sandfjord Formation, Finnmark, North Norway. Sedimentology, 27: 539-557.

Lima, M., Ward, R., and Joyce, C. (2020). Environmental drivers of carbon stocks in temperate seagrass meadows. Hydrobiologia, 847: 1773-1792

Martini, P., Morrison, G., Abraham, K., Sergienko, L., Jefferies, R. (2019). Northern Polar coastal wetlands: development, structure, and land use. In: Perillo, G., Wolanski, E., Cahoon, D. and Hopkinson, C. Coastal wetlands, Elsevier, Netherlands.

MET Norway (2019). Data from The Norwegian Meteorological Institute. www.eKlima.no. Norway.

Ngai, J.T. and Jeffies, R.L. (2004). Nutrient limitation of plant growth and forage quality in Arctic coastal marshes. Journal of Ecology, 92: 1001-1010.

NGU (2017). Norwegian Geological Survey Web Map Server. Norwegian Geological Survey, Norway.

Paatero, J., Vaaramaa, K., Buyukay, M., Hatakka J. and Lehto, J. (2015). Deposition of atmospheric ${ }^{210} \mathrm{~Pb}$ and total beta activity in Finland. Journal Radioanalytical Nuclear Chemistry 303: 2413-2420.

Plater, A.J., Appleby, P.G., 2004. Tidal sedimentation in the Tees estuary during the $20^{\text {th }}$ century: radionuclide and magnetic evidence of pollution and sedimentary response. Estuarine Coastal Shelf Science 60: 179-192. 
772 Ritchie, J.C., McHenry, J.R., (1990). Application of radioactive fallout caesium-137 773 for measuring soil erosion and sediment accumulation rates and patterns: a review. 774 Journal Environmental Quality, 19: 215-233.

775 Roberts, D., Olesen, O. and Karpuz, M.R. (1997). Seismo- and neotectonics in 776 Finnmark, Kola Peninsula and the southern Barents Sea. Part 1: Geological and 777 neotectonic framework. Tectonophysics, 270: 1-13.

778 Romundset, A., Bondevik, S. and Bennike, O. (2011). Postglacial uplift and relative 779 sea level changes in Finnmark, northern Norway. Quaternary Science Reviews, 780 30(19-20): 2398-2421.

781

Rosen, K., Vinichuk, M. and Johanson, K. (2009). 137Cs in a raised bog in central 782 Sweden. Journal of Environmental Radioactivity, 100(7): 534-539.

Saintilan, N., Rogers, K., Kelleway, J.J., Ens E. and Sloane, D.R. (2019). Climate 784 change impacts on the coastal wetlands of Australia. Wetlands, 39: 1145-1154.

Schuerch, M., Spencer, T., Temmerman, S., Kirwan, M., Wolff, C., Lincke, D., 786 McOwen, C., Pickering, M., Reef, R., Vafeidis, A., Hinkel, J., Nicholls, R. and Brown, 787 S. (2018). Future response of global coastal wetlands to sea-level rise. Nature 561: 788 $231-234$.

789

Simpson, M.J.R., Nilsen, J.E.Ø., Ravndal, O.R., Breili, K., Sande, H., Kierulf, H.P., 790 Steffen, H., Jansen, E., Carson, M. and VestøI, O. (2015). Sea level change for 791 Norway: past and present observations and projections to 2100 . Norwegian 792 Environment Agency, Norway.

793 Spencer, T., Schuerch, M., Nicholls, R., Hinkel, J., Lincke, D., Vafeidis, A., Reef, R., 794 McFadden, L. and Brown, S. (2016). Global coastal wetland change under sea-level 
rise and related stresses: The DIVA Wetland Change Model. Global and Planetary Change, 139: 15-30.

Stagg, C.L., Schoolmaster, D.R., Piazza, S.C., Snedden, G., Steyer, G., Fischenich C. and McComas, R. (2017). A landscape-scale assessment of above- and belowground primary production in coastal wetlands: implications for climate changeinduced community shifts. Estuaries and Coasts 40, 856-879.

Symon, C., Arris, L. and Heal, B. (2005). Arctic climate impact assessment. Cambridge University Press, UK.

Teasdale, P., Collins, P., Firth, C. and Cundy, A. (2011). Recent estuarine sedimentation rates from shallow inter-tidal environments in western Scotland: implications for future sea-level trends and coastal wetland development. Quaternary Science Reviews, 30: 109-129.

Thompson, J., Dyer, F.M. and Croudace, I.W., (2001). Records of radionuclide deposition in two U.K. salt marshes in the United Kingdom with contrasting redox and accumulation conditions. Geochimica Cosmochimica Acta, 66: 1011-1023.

Walling, D. and He, Q. (1993). Use of Cesium-137 as a tracer in the study of rates and patterns of floodplain sedimentation. Tracers in Hydrology. IAHS, Japan.

Walsh, J., Fetterer, F., Stewart, S. and Chapman, W. (2017). A database for depicting Arctic sea ice variations back to 1850. Geographical Review, 107: 89-107.

Ward, R., Burnside, N., Joyce, C. and Sepp, K. (2016c). Importance of microtopography in determining plant community distribution in Baltic coastal wetlands. Journal of Coastal Research 32(5): 1062-1070 
817 Ward, R., Burnside, N., Joyce, C., Sepp, K. and Teasdale, P. A. (2014). Recent rates

818 of sedimentation on irregularly flooded Boreal Baltic coastal wetlands: responses to 819 recent changes in sea level Geomorphology 217: 61-72.

820 Ward, R., Burnside, N., Joyce, C., Sepp, K. and Teasdale, P. A. (2016b). Improved 821 modelling of the impacts of sea level rise on coastal wetland plant communities. 822 Hydrobiologia Wetlands Biodiversity \& Processes: 1-14.

823 Ward, R., Friess, D., Day, R., and Mackenzie, R. (2016a). Impacts of climate change 824 on global mangrove ecosystems: a regional comparison. Ecosystem Health and 825 Sustainability $2(4): 1-25$

826 Wentworth, C. (1922). A scale of grade and class terms for clastic sediments. 827 Journal of Geology 30(5): 377-392.

828 Yu, Q., Epstein, H., Engstrom, R. and Walker, D. (2017). Circumpolar Arctic tundra 829 biomass and productivity dynamics in response to projected climate change and 830 herbivory. Global Change Biology 23: 3895-3907. 
Table 1: Average rates of sediment accretion $(\mathrm{mm} / \mathrm{yr})$ derived from the CF:CS and CRS methods using ${ }^{210} \mathrm{~Pb}$ for all five sites as calculated for the low and high marsh zones.

\begin{tabular}{lcc}
\hline Site and ecological zone & $\begin{array}{c}\text { Average CRS } \\
\text { accretion rate }\end{array}$ & $\begin{array}{c}\text { CF:CS accretion } \\
\text { rate }\end{array}$ \\
\hline Alta lower shore & 1.8 & $1.7(1.0,2.7)$ \\
$\begin{array}{l}\text { Alta upper shore } \\
\text { Stabbursnes lower }\end{array}$ & 0.9 & $0.7(0.6,0.9)$ \\
shore & 1 & $0.5(0.3,0.8)$ \\
Stabbursnes upper & 1.2 & $0.5(0.3,0.8)$ \\
shore & 1 & $0.8(0.7,0.9)$ \\
Birtvarre lower shore & 0.7 & $0.5(0.3,0.7)$ \\
Birtvarre upper shore & 0.5 & $0.3(0.2,0.4)$ \\
Storfjord lower shore & 1.3 & $0.3(0.2,0.4)$ \\
Storfjord upper shore & 1.5 & $1.5(1.1,2.5)$ \\
Storslett lower shore & 0.3 & $0.2(0.1,0.3)$ \\
Storslett upper shore & & \\
\hline
\end{tabular}


Table 2: Average rates of sediment accretion ( $\mathrm{mm} / \mathrm{yr}$ ) derived from ${ }^{210} \mathrm{~Pb}$ and ${ }^{137} \mathrm{Cs}$ dating methods for all five sites as calculated for the low and high marsh zone data since 1963 and 1986 for comparison.

\begin{tabular}{lcccc}
\hline Site and ecological zone & $\begin{array}{c}{ }^{210} \mathrm{~Pb} \text { CRS } \\
\text { sediment } \\
\text { accretion since } \\
1963\end{array}$ & $\begin{array}{c}{ }^{210} \mathrm{~Pb} \text { CRS } \\
\text { sediment } \\
\text { accretion since } \\
1986\end{array}$ & $\begin{array}{c}{ }^{137} \text { Cs sediment } \\
\text { accretion since } \\
1963\end{array}$ & $\begin{array}{c}{ }^{137} \text { Cs sediment } \\
\text { accretion since } \\
1986\end{array}$ \\
\hline Alta lower shore & 1.9 & 2.4 & 1.3 & 1.5 \\
Alta upper shore & 1.0 & 1.1 & 1.6 & 2.1 \\
Stabbursnes lower shore & 1.8 & 1.0 & 1.1 & 1.3 \\
Stabbursnes upper shore & 1.3 & 0.5 & 0.8 & 1.0 \\
Birtvarre lower shore & 1.6 & 1.1 & 1.1 & 0.6 \\
Birtvarre upper shore & 0.8 & 0.7 & 1.1 & 1.3 \\
Storfjord lower shore & 0.5 & 0.5 & 1.9 & 2.0 \\
Storfjord upper shore & 0.4 & 0.4 & 1.5 & 0.9 \\
Storslett lower shore & 1.7 & 1.8 & 1.7 & 1.7 \\
Storslett upper shore & 0.3 & 0.3 & 0.7 & 0.4 \\
\hline
\end{tabular}


Table 3: Maximum average rates of sediment accretion derived from the CRS method, galcio-isostatic adjustement (GIA) corrected rates of sea level rise (SLR), and net sea level rise within the sites taking into account GIA, eustatic forcing and sediment accretion.

\begin{tabular}{lccc}
\hline Sites & $\begin{array}{c}\text { Sediment } \\
\text { accretion }\end{array}$ & $\begin{array}{c}\text { GIA } \\
\text { corrected } \\
\text { SLR }\end{array}$ & $\begin{array}{c}\text { Local SLR } \\
\text { at sites }\end{array}$ \\
\hline Alta & 1.8 & 2.2 & 0.4 \\
Stabbursnes & 1.2 & 2.8 & 1.6 \\
Birtvarre & 1.0 & 2.2 & 1.2 \\
Storfjord & 1.3 & 2.2 & 0.9 \\
Storslett & 1.5 & 2.2 & 0.7 \\
\hline
\end{tabular}


Table 4: Current area of the coastal wetlands at each site. Predicted area of the wetland as a result of local sea level rise is shown together with the percentage total loss. Care should be taken that this does not account for environmental feedback, nor factors other than sea level rise including potential for migration inland.

\begin{tabular}{lccc}
\hline Sites & Original area (ha) & $\begin{array}{c}\text { Predicted area } \\
\text { (ha) }\end{array}$ & \% loss \\
\hline Alta & 77.3 & 21.5 & 72.2 \\
Stabbursnes & 107.8 & 12.8 & 88.1 \\
Birtvarre & 22.8 & 10.2 & 55.3 \\
Storfjord & 10.1 & 6.9 & 31.7 \\
Storslett & 84.3 & 59.1 & 29.9 \\
\hline
\end{tabular}




\section{(Color)}

Click here to download high resolution image

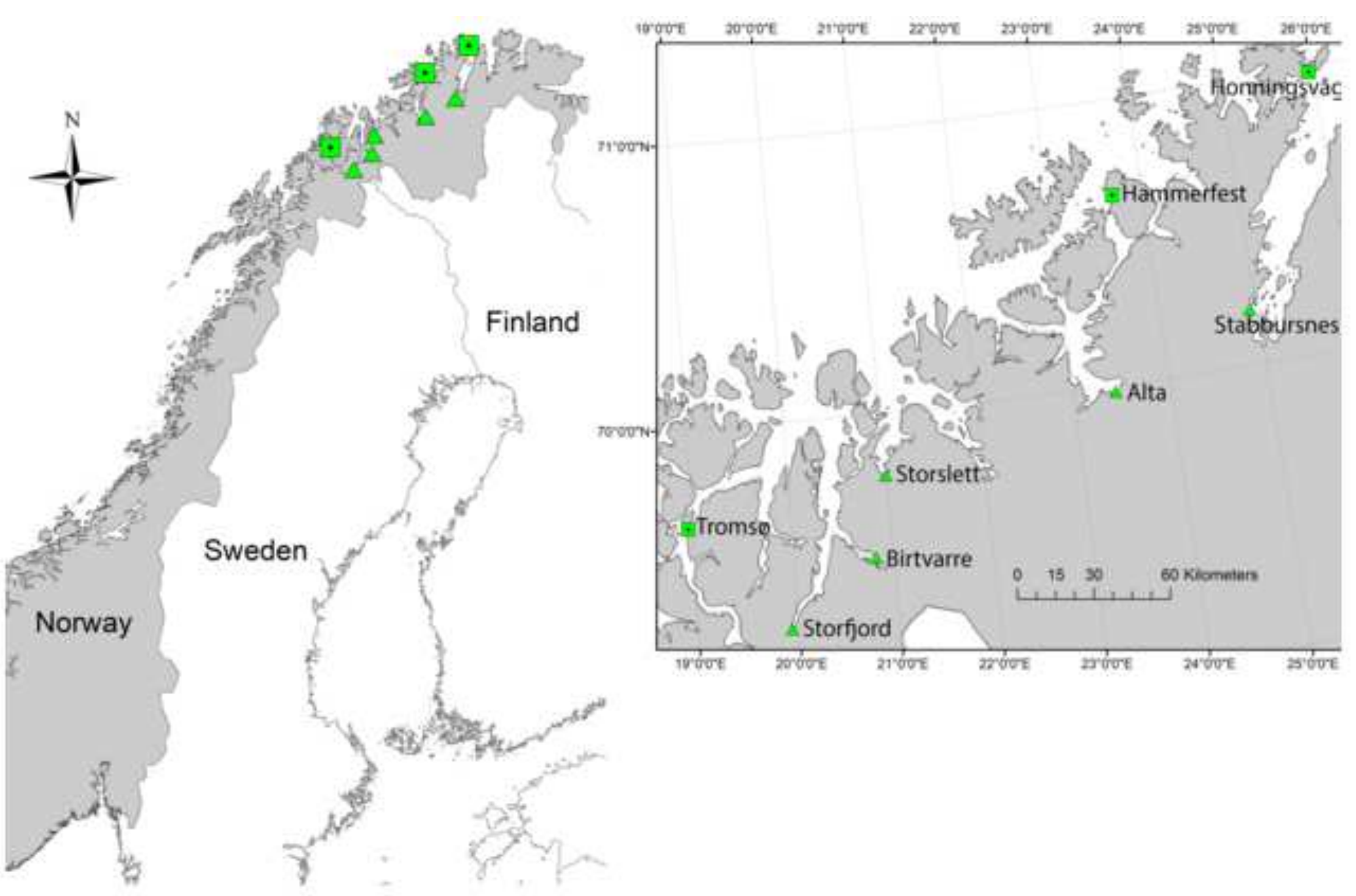


Click here to download high resolution image

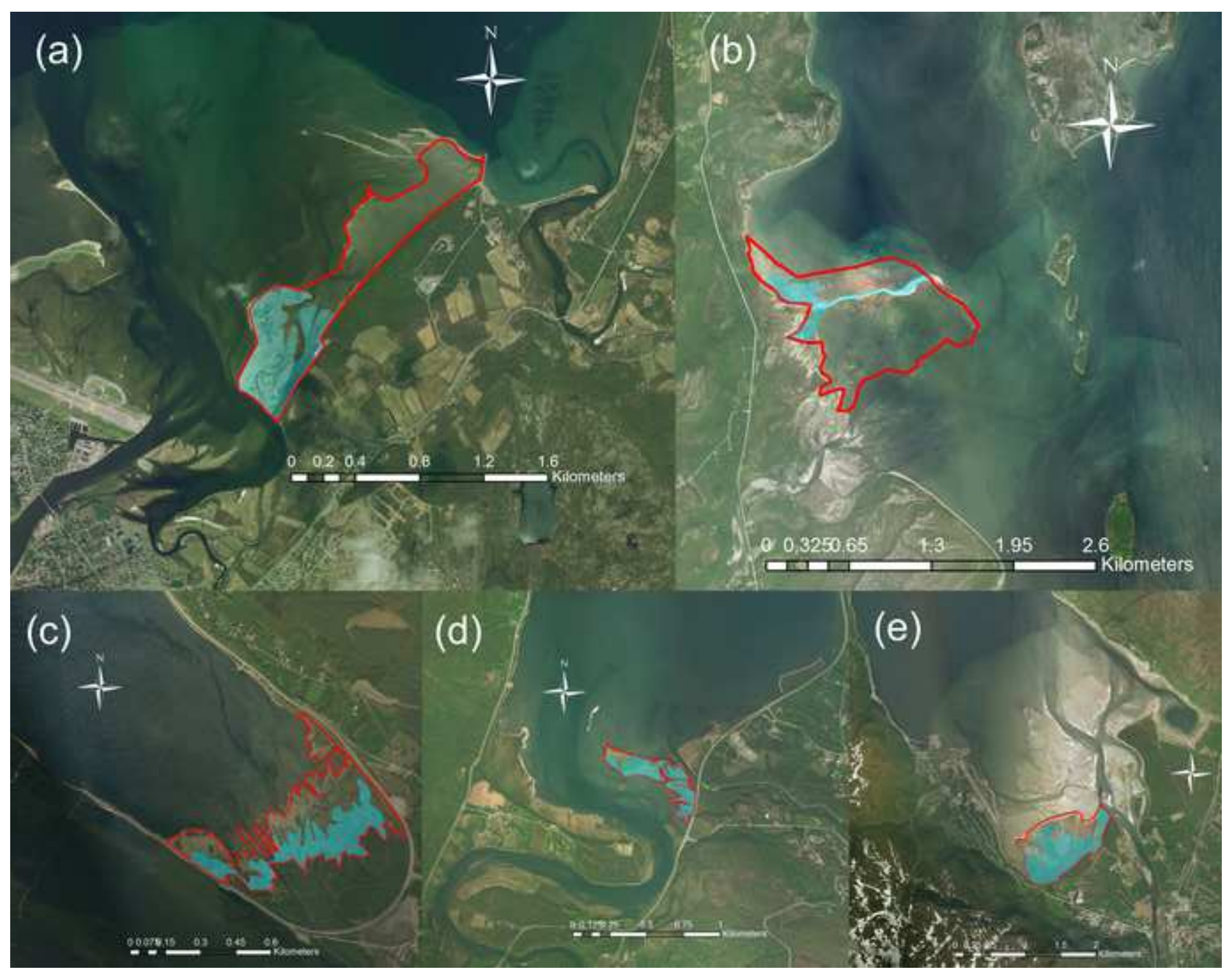

(a)

(b)

(d) 
Click here to download high resolution image
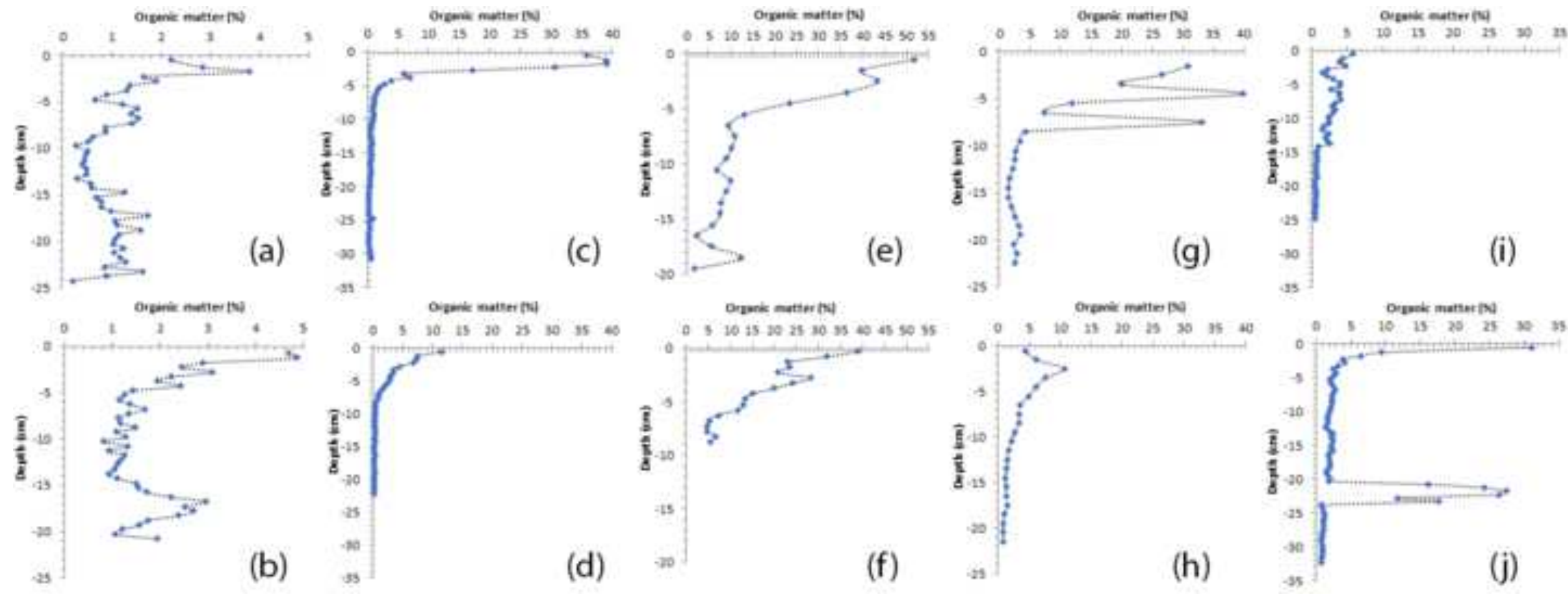

Oremit metter in

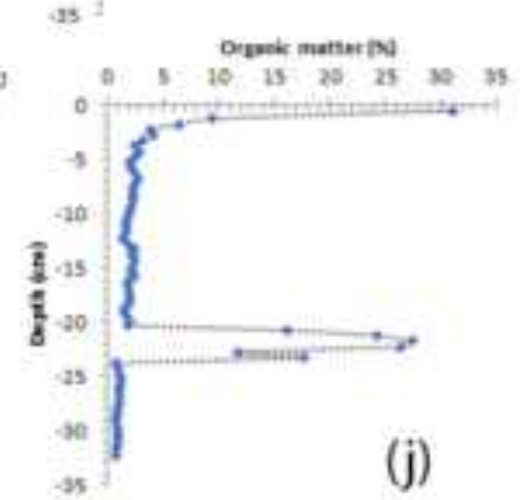

(h) 
Click here to download high resolution image
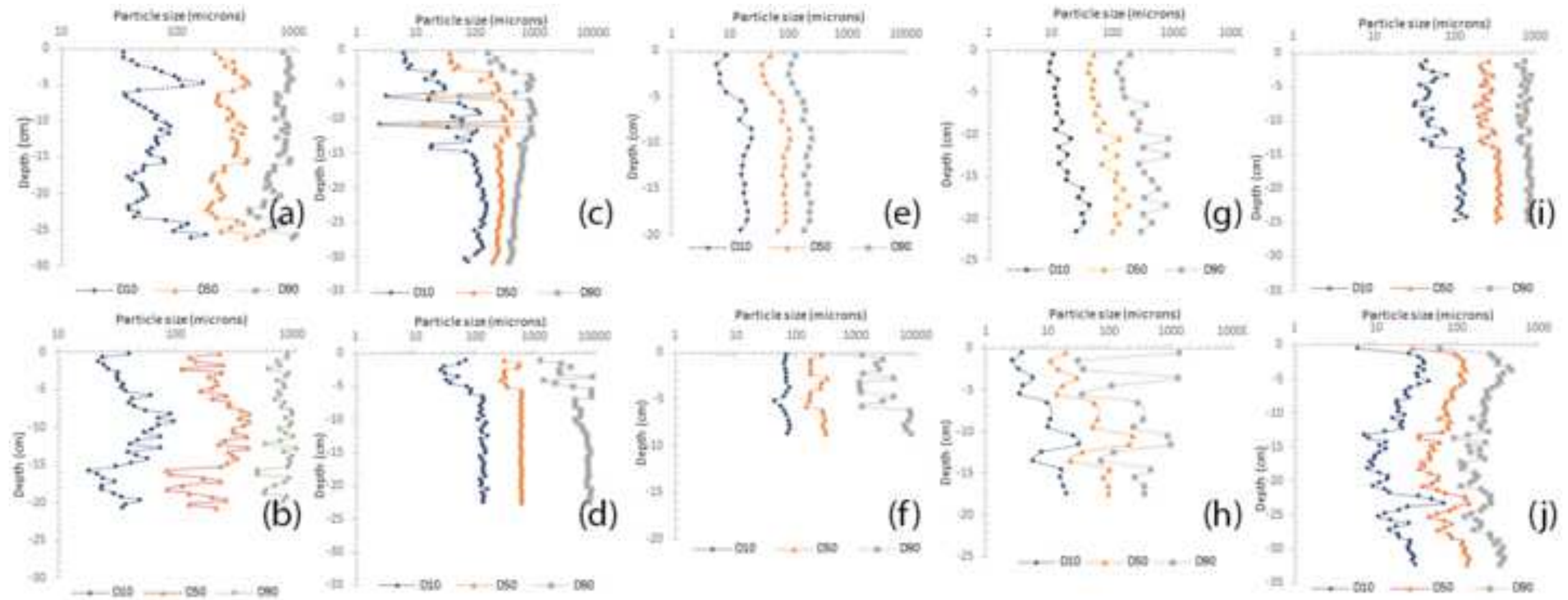


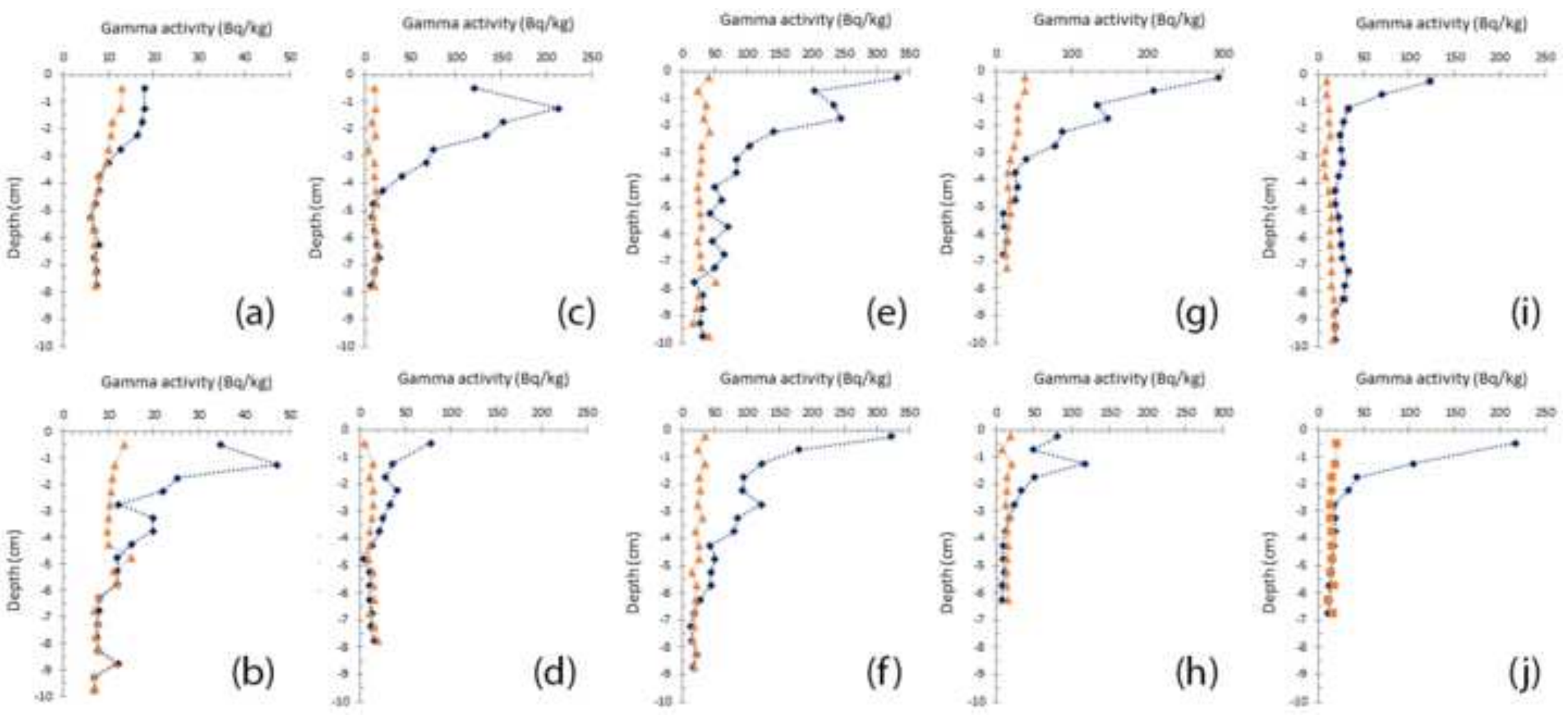

(j) 

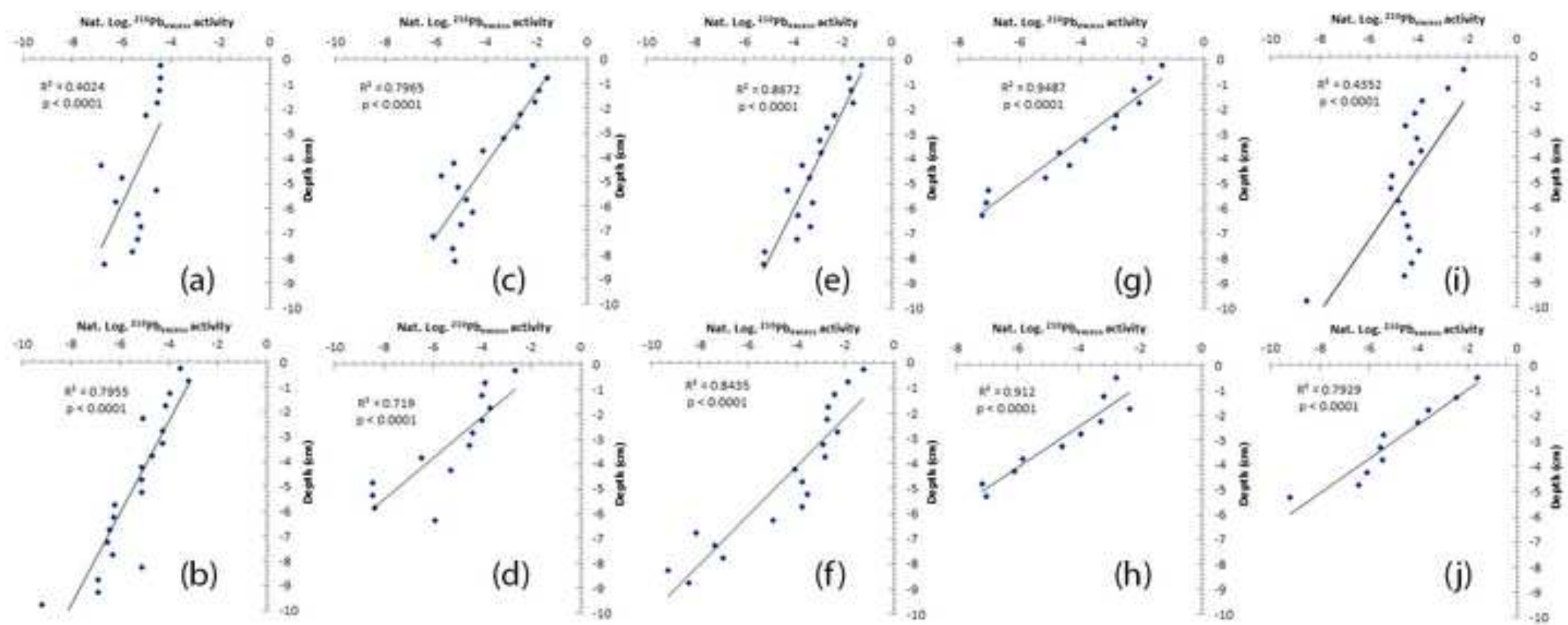


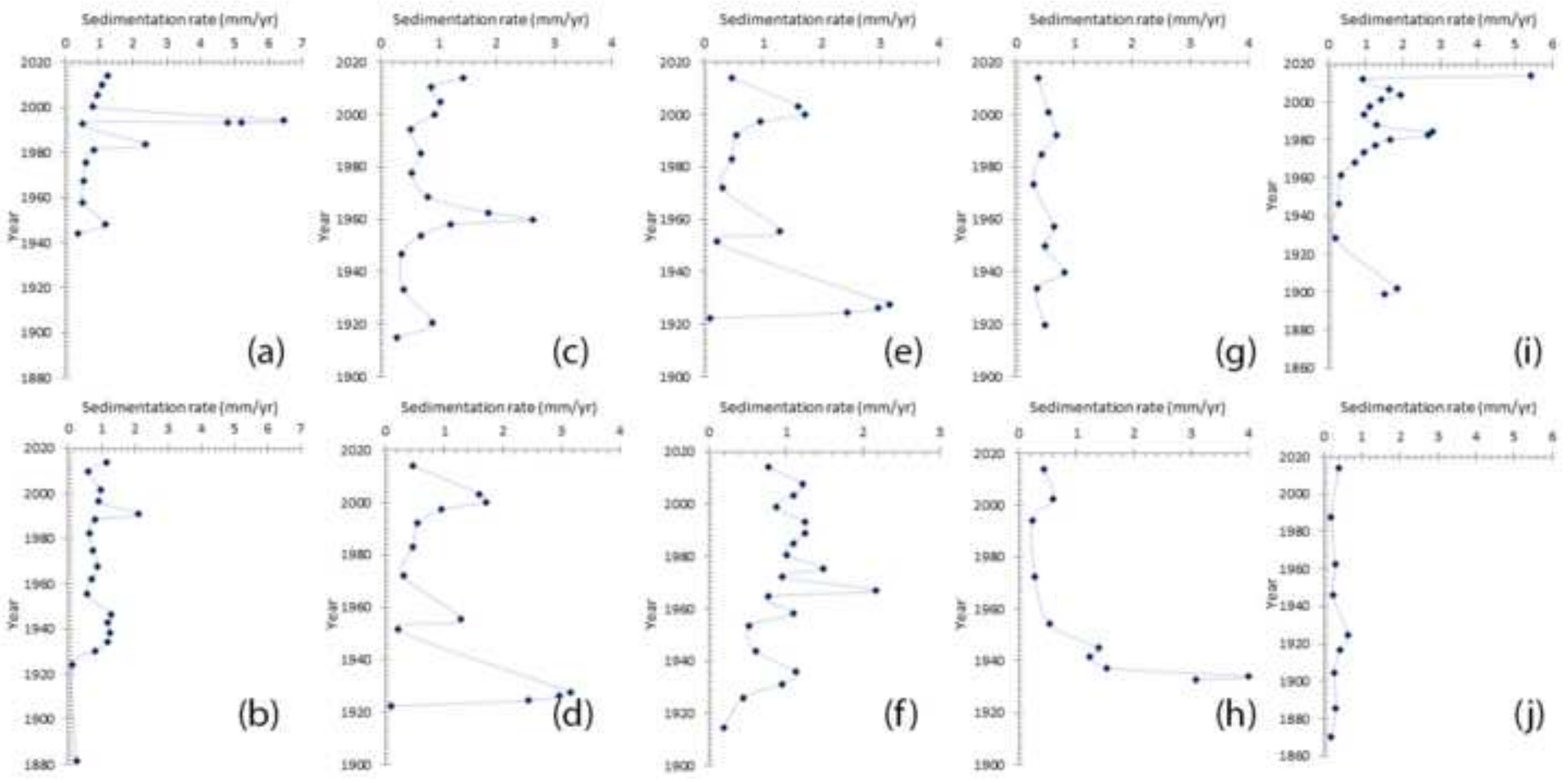



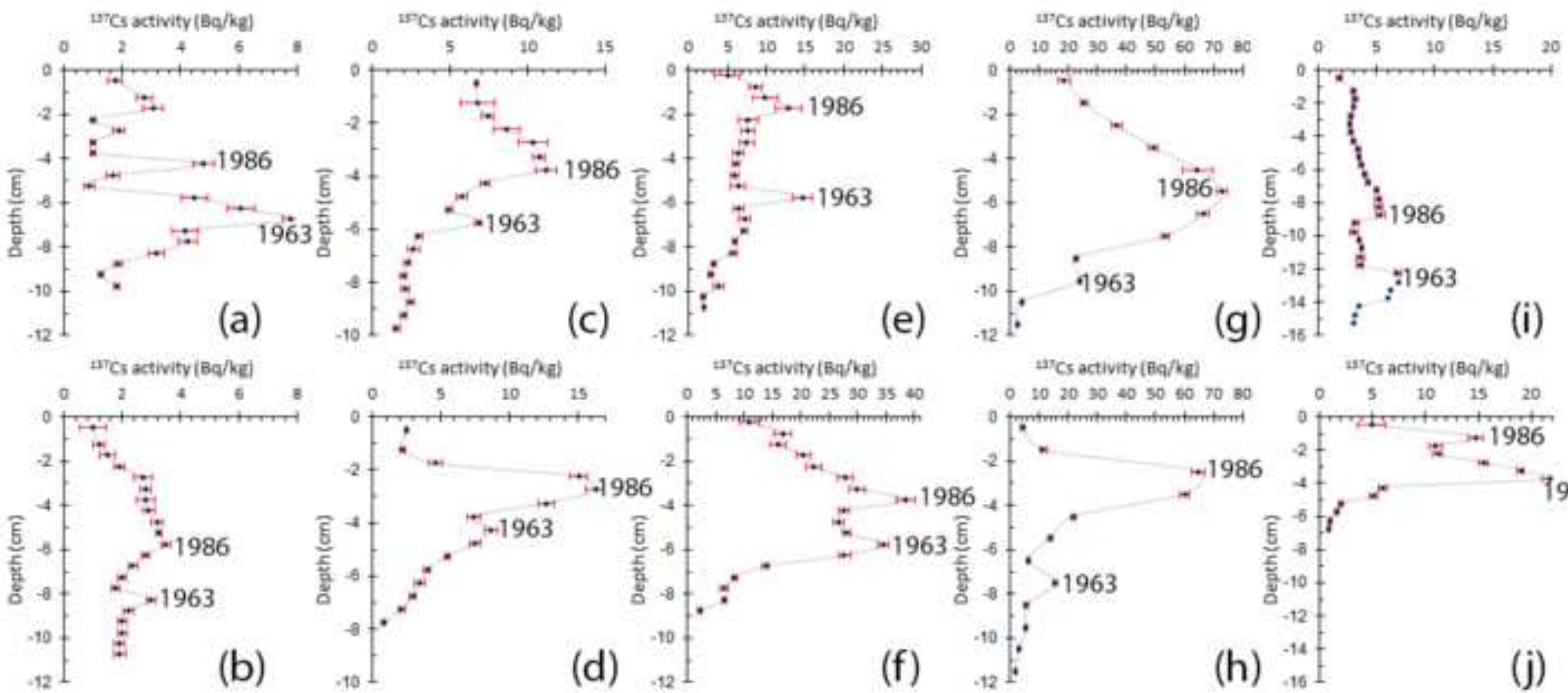

wes activity $(\mathrm{Bq} / \mathrm{kg})$

in $\mathrm{Cs}$ activity $(\mathrm{Bg} / \mathrm{kg})$

wis activity $(8 \mathrm{~g} / \mathrm{kg})$

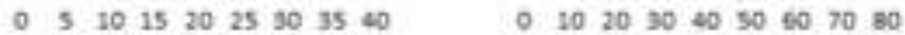
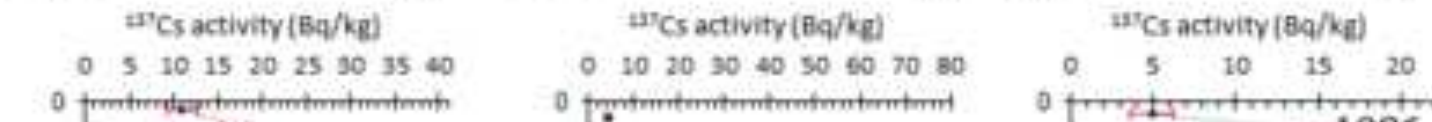

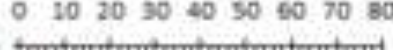

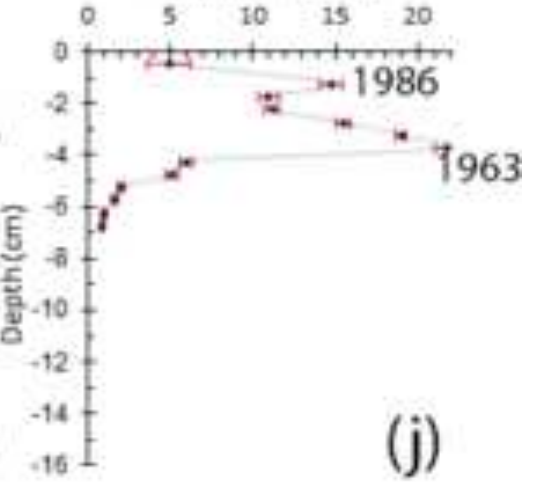

(f)

(h)

(j) 


\section{${ }^{*}$ Declaration of Interest Statement}

\section{Declaration of interests}

$\bigotimes$ The author declares that they have no known competing financial interests or personal relationships that could have appeared to influence the work reported in this paper. 